\title{
Efficiency of methionine retention in ducks
}

\author{
Olayiwola Adeola* \\ Department of Animal Sciences, Purdue University, West Lafayette, Indiana, USA
}

(Received 8 June 2006 - Revised 15 September 2006 - Accepted 9 October 2006)

\begin{abstract}
The accretion of methionine and protein as a function of methionine intake was assessed in growing ducks between 22 and $42 \mathrm{~d}$ post-hatching. Four graded doses of DL-methionine at $0,0.5,1.0$ or $1.5 \mathrm{~g} / \mathrm{kg}$ diet were added to a methionine-limiting basal diet and fed to four replicate groups of four ducks each. The growth and efficiency of food use for growth increased linearly $(P<0.05)$ as a function of methionine intake. The accretion of body protein increased $(P<0.001)$ from 87.5 to $182.2 \mathrm{~g}$, and that of methionine from 1616 to $3125 \mathrm{mg}$, over the $21 \mathrm{~d}$ period as dietary methionine increased. The accretion rate of methionine in the body $(\mathrm{y}, \mathrm{mg} / \mathrm{d})$ as a function of methionine intake $(\mathrm{x}, \mathrm{mg} / \mathrm{d})$ of ducks fed diets containing supplemental methionine at $0,0.5,1.0$ or $1.5 \mathrm{~g} / \mathrm{kg}$ diet from day 22 to day 42 post-hatching gave the regression equation: $\mathrm{y}=-148.86$ $(\mathrm{SE} 32.558)+0.312(\mathrm{SE} 0.0384) \mathrm{X}, r^{2}=0.8253$. For protein accretion rate in the body $(\mathrm{y}, \mathrm{mg} / \mathrm{d})$ as a function of methionine intake (x, mg/d), the regression equation was: $\mathrm{y}=-9782(\mathrm{SE} 2204)+19.505(\mathrm{SE} 2.5994) \mathrm{x}, r^{2}=0.8009$. There was a linear relationship between methionine $(\mathrm{y}, \mathrm{mg} / \mathrm{d})$ and protein $(\mathrm{x}, \mathrm{mg} / \mathrm{d})$ accretion in ducks that was described by the equation $\mathrm{y}=12.757$ (SE 7.4019) + 0.01525 (SE 0.00 107) $\mathrm{x}$, $r^{2}=0.9355$. The results of these studies suggest a constant utilisation of methionine over the range $2 \cdot 4-3.9 \mathrm{~g}$ digestible methionine/kg diet, with an efficiency of $31 \%$. Furthermore, the results suggest a quantitative relationship of $15 \mathrm{mg}$ methionine for every gram of protein accretion.
\end{abstract}

Amino acids: Ducks: Methionine: Protein: Retention efficiency

The development of accurate models of nutritional requirements for amino acids of necessity calls for a knowledge of maintenance requirements, efficiencies of utilisation of amino acids for protein accretion, and quantitative relationships between the accretion of protein and amino acids. The amount of dietary protein that must be supplied is dependent on the efficiency with which dietary protein is used for body functions. However, the efficiency of dietary protein utilisation is not necessarily equal to that of individual amino acids (Baker, 1991; Chung \& Baker, 1992).

Thus, data on dietary protein utilisation provide no knowledge on the efficiency of utilisation of individual amino acids, and there is evidence in pigs, chickens and rats that these efficiencies are not equal between amino acids within species (Gahl et al. 1991; Batterham et al. 1990; Bikker et al. 1994; Adeola, 1995; Baker et al. 1996; Sklan \& Noy, 2004). Adeola (1995) reported that lysine was retained more efficiently than threonine in pigs. Edwards et al. (1997, 1999), and Edwards \& Baker (1999), reported that the efficiency of dietary threonine, lysine and methionine retention in young chicks was $82 \%, 79 \%$ and $68 \%$, respectively. Estimates of the efficiency of amino acid retention for ducks are limited. Timmler \& Rodehutscord (2003) presented data suggesting that the efficiency of retaining valine was $49 \%$ in ducks between 0 and $21 \mathrm{~d}$ post-hatching. In an earlier study, Adeola (1998) evaluated tryptophan accretion as a function of tryptophan intake in 42-d-old ducks and observed that the efficiency of tryptophan retention was $21 \%$.

Because of the importance of methionine as a limiting amino acid for non-ruminant animals and the paucity of estimates of efficiency of methionine utilisation for protein and methionine accretion in ducks, the study reported here was designed to investigate methionine retention in the growing duck.

\section{Materials and methods}

\section{General procedures}

Purdue University Animal Care and Use Committee approved all housing and handling procedures. White Pekin drakes were obtained from Maple Leaf Farms (Syracuse, IN, USA) $1 \mathrm{~d}$ post-hatching and housed in pens $(1.52 \times 2.44 \mathrm{~m})$ with raised, plastic-coated wire floors $(1.52 \times 0.81 \mathrm{~m})$ over gutters. The ducklings had free access to a commercial nutrient-adequate duck starter diet and water for $21 \mathrm{~d}$ on a regimen of $23 \mathrm{~h} / \mathrm{d}$ light.

On day 22, the drakes were weighed, wing-banded and divided into experimental groups. An experimental group of twelve drakes served as an initial slaughter group. Furthermore, there were sixteen groups of four drakes each that were assigned to four diets as indicated below. Four graded doses of DL-methionine at $0,0.5,1.0$ or $1.5 \mathrm{~g} / \mathrm{kg}$ diet were added to a basal diet. The sixteen groups of ducks were blocked on the basis of weight with four groups per block. Each block of similar weight was then randomly allotted to each of the four diets. Individual body weight and cage food intake were recorded weekly, and access to food and water was provided ad libitum for $21 \mathrm{~d}$. The ingredient composition as well as analysed nutrient content of the basal diet are 
presented in Table 1. All amino acids, except methionine, in the basal diet met National Research Council (1994) requirements for 2-7-week-old ducks. As a part of the current study, amino acid digestibility coefficients and $\mathrm{N}$-corrected true metabolisable energy were determined in the basal diet using procedures previously described (Ragland et al. 1999). The product of amino acid digestibility coefficient and analysed amino acid concentration was used as the digestible amino acid concentration. Diets containing the graded doses of methionine were formulated by supplementing the basal diet with DL-methionine at the expense of corn starch.

\section{Analytical procedures}

At the end of the feeding period, feed was withdrawn for $12 \mathrm{~h}$. The ducks were shipped to the Animal Sciences Meat Laboratory where they were electrically stunned and killed. The whole body was subsequently frozen, sliced into strips and homogenized. Samples of homogenates were lyophilized. DM was determined

Table 1. Ingredient composition $(\mathrm{g} / \mathrm{kg})$ of the basal diet on an as-fed basisł

\begin{tabular}{|c|c|}
\hline Ingredient & Composition \\
\hline Corn & 320 \\
\hline Corn gluten meal & 160 \\
\hline Sucrose & 100 \\
\hline Skimmed milk powder (34\% CP) & 30 \\
\hline Casein & 25 \\
\hline Corn oil & 40 \\
\hline Solka floc & 30 \\
\hline Crystalline amino acid premix & 30 \\
\hline Dicalcium phosphate & 16 \\
\hline Limestone & 10 \\
\hline Salt & 4 \\
\hline Minerals and vitamins $\ddagger$ & 3 \\
\hline Corn starch§ & 232 \\
\hline Total & 1000 \\
\hline \multicolumn{2}{|l|}{ Analyzed nutrient $(\mathrm{g} / \mathrm{kg})$ and energy $(\mathrm{MJ} / \mathrm{kg})$} \\
\hline Crude protein $(\mathrm{N} \times 6.25)$ & $165 \cdot 8$ \\
\hline $\mathrm{N}$-corrected true metabolisable energy\| & $14 \cdot 8$ \\
\hline $\mathrm{Ca}$ & $7 \cdot 5$ \\
\hline $\mathrm{P}$ & 4.8 \\
\hline Ca:P & 1.6 \\
\hline Non-phytate $\mathrm{P}$ & 3.6 \\
\hline \multicolumn{2}{|l|}{ Total amino acids } \\
\hline Arg & $10 \cdot 8$ \\
\hline His & 4.5 \\
\hline Ile & 7.6 \\
\hline Leu & 23.4 \\
\hline Lys & $12 \cdot 2$ \\
\hline Met & 3.7 \\
\hline Cys & $7 \cdot 5$ \\
\hline Phe & $10 \cdot 1$ \\
\hline Tyr & 8.5 \\
\hline Thr & 8.4 \\
\hline Trp & 1.5 \\
\hline Val & $9 \cdot 2$ \\
\hline
\end{tabular}

¥Composed of the following (per kg diet): retinol $1.65 \mathrm{mg}$, cholecalciferol $66 \mathrm{mg}$, DL- $\alpha$ tocopherol $10 \mathrm{mg}$, menadione sodium bisulfite $438 \mathrm{mg}$, riboflavin $5.49 \mathrm{mg}$, D-pantothenic acid $11 \mathrm{mg}$, niacin $44.1 \mathrm{mg}$, choline chloride $771 \mathrm{mg}$, cyanocobalamin, $13.2 \mathrm{mg}$, biotin $55.2 \mathrm{mg}$, thiamine monocitrate $2.2 \mathrm{mg}$, folic acid $990 \mathrm{mg}$, pyridoxine hydrochloride $3.3 \mathrm{mg}$, I $1.11 \mathrm{mg}, \mathrm{Mn} 66 \mathrm{mg}, \mathrm{Cu} 4.44 \mathrm{mg}, \mathrm{Fe}$ $44.1 \mathrm{mg}$, Zn $44.1 \mathrm{mg}$, Se $300 \mathrm{mg}$.

$\S \mathrm{DL}-$ methionine replaced corn starch in the test diets.

|| Determined using procedures referenced in Materials and Methods. by drying the samples at $105^{\circ} \mathrm{C}$ for $24 \mathrm{~h}$. Ether-extractable fat content was assessed by extracting the lyophilized samples in diethyl ether and drying the extract at $105^{\circ} \mathrm{C}$ for $12 \mathrm{~h}$. The lyophilized samples were burned in a muffle furnace at $550^{\circ} \mathrm{C}$ for $24 \mathrm{~h}$ to determine the ash content. $\mathrm{N}$ content was determined by the combustion method using a LECO model FP-2000 Nitrogen Analyzer (LECO, St Joseph, MI, USA).

Amino acid analyses were conducted at the University of Missouri Experiment Station Chemical Laboratory. Samples for amino acid analysis were prepared using $24 \mathrm{~h}$ hydrolysis in $6 \mathrm{M}-\mathrm{HCl}$ at $110^{\circ} \mathrm{C}$ under an atmosphere of $\mathrm{N}$. For methionine and cysteine, samples were oxidized in performic acid before acid hydrolysis. Samples for tryptophan analysis were hydrolyzed using $\mathrm{Ba}(\mathrm{OH})_{2}$. Amino acids in hydrolysates were determined by HPLC after post-column derivatization (Association of Official Analytical Chemists, 2000).

\section{Statistical analysis}

Data were subjected to the generalized linear models procedure (SAS Institute, 2003) using the following model:

$$
\mathrm{y}_{\mathrm{ijk}}=\mu+\mathrm{B}_{\mathrm{i}}+\mathrm{D}_{\mathrm{j}}+\mathrm{E}_{\mathrm{ijk}}
$$

where $\mathrm{y}$ is the response criterion, $\mu$ is the overall mean, $\mathrm{B}_{\mathrm{i}}$ represents the effect of ith block $(i=1,2,3,4), D_{j}$ represents the effect of $j$ th diet $(j=1,2,3,4)$ and $E_{i j k}$ is the error term. Linear and quadratic contrasts were used to examine the relationship between response and dietary methionine. For methionine accretion data, simple linear regression analysis was conducted using the generalized linear models procedure. In the analysis, we regressed the methionine accretion for the mean of four ducks per cage on the average methionine intake to obtain the relationship between accretion and intake of methionine; and the quantitative relationship between methionine and protein accretion was derived from the linear regression of methionine accretion on protein accretion. Mean differences were considered significant at $P<0 \cdot 05$.

\section{Results}

The addition of up to $1.5 \mathrm{~g}$ methionine to each kilogram of the methionine-deficient basal diet linearly increased $(P<0.001)$ body weight gain and food efficiency of the ducks (Table 2).

Table 2. The weight gain, food intake and food efficiency of ducks fed diets containing supplemental methionine at $0,0.5,1.0$ or $1.5 \mathrm{~g} / \mathrm{kg}$ diet for $21 \mathrm{~d}$

\begin{tabular}{lrrrrr}
\hline & \multicolumn{5}{c}{ Supplemental dietary methionine } \\
& \multicolumn{4}{c}{$(\mathrm{g} / \mathrm{kg}$ diet) } \\
\cline { 2 - 5 } & \multicolumn{1}{c}{0} & 0.5 & 1.0 & 1.5 & SEM \\
\hline Initial weight $(\mathrm{g})$ & 1343 & 1339 & 1336 & 1337 & 36.76 \\
Final weight $(\mathrm{g})^{\star \star \star}$ & 2171 & 2565 & 2705 & 2859 & 79.26 \\
Weight gain $(\mathrm{g})^{\star \star \star}+\dagger$ & 828 & 1226 & 1369 & 1522 & 53.23 \\
Food intake $(\mathrm{g})$ & 4370 & 4475 & 4531 & 4468 & 78.84 \\
Gain:food $(\mathrm{g} / \mathrm{kg})^{\star \star *} \dagger$ & 190 & 275 & 302 & 341 & 11.77 \\
\hline
\end{tabular}

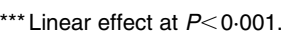

† Quadratic effect at $P<0.10$.

††Quadratic effect at $P<0.05$. 
Methionine supplementation also resulted in a quadratic effect on body weight $(P<0.05)$ and food efficiency $(P<0 \cdot 10)$. The increase in body weight gain and food efficiency as a result of adding methionine to the basal diet was not caused by changes in food intake of the ducks as there was no effect on food intake (Table 2). There was a linear increase $(P<0 \cdot 01)$ in body ash content as supplemental methionine in the basal diet offered to ducks increased from 0 to $1.5 \mathrm{~g} / \mathrm{kg}$ (Table 3 ). Whereas ether-extractable fat contents linearly decreased $(P<0.01)$ with added dietary methionine, there was a linear increase $(P<0.05)$ in protein. Most of the amino acids in the body protein except arginine, cysteine, methionine and threonine were unaffected by supplementation with methionine.

The accretion of body DM, ash, ether extract, protein and methionine increased linearly $(P<0.001)$ as supplemental methionine in the basal diet offered to the ducks increased from 0 to $1.5 \mathrm{~g} / \mathrm{kg}$ (Table 4 ). The linear regression of body methionine accretion rate $(\mathrm{y}, \mathrm{mg} / \mathrm{d})$ against daily digestible methionine intake $(\mathrm{x}, \mathrm{mg} / \mathrm{d})$ was described by the line: $\mathrm{y}=-148.86 \quad(\mathrm{SE} 32.558)+0.312 \quad(\mathrm{SE}$ 0.0384)x, $r^{2}=0.8253$ (Fig. 1). This indicated that approximately $31 \%$ of digestible methionine intake was deposited in the body of the ducks during the growth period between 22 and $42 \mathrm{~d}$ post-hatching.

The daily accretion of protein $(\mathrm{y}, \mathrm{mg} / \mathrm{d})$ as a linear function of daily digestible methionine intake $(\mathrm{x}, \mathrm{mg} / \mathrm{d})$ was described by the equation: $\mathrm{y}=-9782(\operatorname{SE} 2204)+19 \cdot 505(\operatorname{SE} 2 \cdot 5994) \mathrm{x}$, $r^{2}=0.8009$ (Fig. 2). On the basis of extrapolation of the regression equation to the $y$ intercept, there was a net daily loss of $9.8 \mathrm{~g}$ body protein in ducks at zero methionine intake. Fig. 3 depicts the linear regression of daily body methionine accretion $(\mathrm{y}, \mathrm{mg} / \mathrm{d})$ on protein accretion $(\mathrm{x}, \mathrm{mg} / \mathrm{d})$. The regression equation, $\mathrm{y}=12.757 \quad(\mathrm{SE}=7.4019)+0.01525$ $(\mathrm{SE}=0.00107) \mathrm{x}, r^{2}=0.9355$, indicated that the accretion of body methionine increased by $15.3 \mathrm{mg}$ for every $1 \mathrm{~g}$ increase in protein accretion.

\section{Discussion}

The responses of ducks to dietary methionine supplementation in terms of body weight gain and the efficiency of conversion of food to body weight in the current study confirms that methionine was the first limiting amino acid in the basal diet. In agreement with a previous study reported by Elkin et al. (1986), increasing digestible methionine from $2 \cdot 4$ to $3.9 \mathrm{~g} / \mathrm{kg}$ feed improved the body weight gain and food efficiency of 22-42-d-old ducks in the current study.

In studies with other amino acids, Oluyemi \& Fetuga (1978) observed improvements in weight gain and food efficiency with increasing dietary lysine in ducks, and Chen \& Shen (1979) reported improvements in weight gains and food efficiency with increasing dietary arginine in ducks. Wu et al. (1984), in a study of the response of 8-20-d-old Mule ducklings to dietary tryptophan, observed a $32 \%$ and $25 \%$ improvement in weight gain and food efficiency, respectively, when dietary tryptophan was increased from 1.3 to $2.8 \mathrm{~g} / \mathrm{kg}$ feed. In more recent studies with White Pekin ducks, Adeola (1998) and Timmler \& Rodehutscord (2003) reported body weight gain and food efficiency responses to dietary tryptophan and valine, respectively. The restriction imposed by the limiting amino acid on the use of other amino acids in the current study was presumably alleviated as dietary methionine increased, hence the observed increase in body weight gain and food efficiency responses to dietary methionine supplementation. The data from the current study demonstrate that dietary methionine did not affect voluntary food intake, and illustrate that the ducks used in the current study grew and gained protein and methionine in response to the quantity of methionine consumed.

Table 3. Body DM, ash, ether extract, protein and amino acids of ducks fed diets containing supplemental methionine at $0,0.5,1.0$ or $1.5 \mathrm{~g} / \mathrm{kg}$ diet for $21 \mathrm{~d}$

\begin{tabular}{|c|c|c|c|c|c|}
\hline & \multicolumn{4}{|c|}{ Supplemental dietary methionine ( $\mathrm{g} / \mathrm{kg}$ diet) } & \multirow[b]{2}{*}{ SEM } \\
\hline & 0 & 0.5 & $1 \cdot 0$ & 1.5 & \\
\hline $\mathrm{DM}(\mathrm{g} / \mathrm{kg})$ & 396 & 404 & 405 & 402 & 6.96 \\
\hline Ash $(\mathrm{g} / \mathrm{kg}) \ddagger^{\star *}$ & $58 \cdot 8$ & $61 \cdot 2$ & $67 \cdot 2$ & $70 \cdot 4$ & 2.72 \\
\hline Ether extract $(\mathrm{g} / \mathrm{kg}) \ddagger^{\star \star}$ & 591 & 565 & 550 & 517 & $12 \cdot 48$ \\
\hline Protein $(\mathrm{g} / \mathrm{kg}) \ddagger^{*}$ & 322 & 327 & 354 & 362 & $12 \cdot 37$ \\
\hline \multicolumn{6}{|c|}{ Amino acids ( $\mathrm{g} / \mathrm{kg}$ protein) } \\
\hline $\mathrm{Arg}^{*}$ & $70 \cdot 37$ & 69.89 & $71 \cdot 11$ & 71.57 & 0.416 \\
\hline Cys* & $11 \cdot 24$ & $10 \cdot 72$ & 11.79 & 11.77 & 0.212 \\
\hline His & 31.33 & 31.48 & 32.01 & 31.74 & 0.326 \\
\hline Ile & 32.63 & 32.53 & 33.08 & $33 \cdot 16$ & 0.459 \\
\hline Leu & 71.91 & 71.82 & $72 \cdot 70$ & 73.04 & 0.901 \\
\hline Lys & 65.39 & 64.91 & 65.93 & $66 \cdot 24$ & 0.773 \\
\hline Met $^{*}$ & $17 \cdot 26$ & $16 \cdot 54$ & 17.00 & $18 \cdot 17$ & 0.336 \\
\hline Phe & 43.49 & $43 \cdot 18$ & 43.91 & 44.04 & 0.520 \\
\hline Thr* & 38.76 & 37.50 & 40.64 & $40 \cdot 61$ & 0.614 \\
\hline Trp & 7.46 & 7.46 & 7.54 & 7.58 & 0.089 \\
\hline Val & $42 \cdot 51$ & $42 \cdot 44$ & 42.97 & $43 \cdot 17$ & 0.532 \\
\hline
\end{tabular}

* Linear effect at $P<0.05$

${ }^{\star *}$ Linear effect at $P<0.01$

$\ddagger$ Ash, ether extract and protein are expressed on a DM basis; protein $=\mathrm{N} \times 6.25$. 
Table 4. Accretion of body DM, ash, ether extract, protein and methionine of ducks fed diets containing supplemental methionine at $0,0.5,1.0$ or $1.5 \mathrm{~g} / \mathrm{kg}$ diet for $21 \mathrm{~d}$

\begin{tabular}{|c|c|c|c|c|c|}
\hline & \multicolumn{4}{|c|}{ Supplemental dietary methionine ( $\mathrm{g} / \mathrm{kg}$ diet) } & \multirow[b]{2}{*}{ SEM } \\
\hline & 0 & 0.5 & $1 \cdot 0$ & 1.5 & \\
\hline Dry matter $(\mathrm{g})^{\star \star \star}$ & 274.49 & $403 \cdot 88$ & 451.59 & 504.05 & $25 \cdot 517$ \\
\hline Ash $(g)^{\star \star \star}$ & $16 \cdot 33$ & 24.67 & 30.43 & 35.52 & $2 \cdot 185$ \\
\hline Ether extract $(g)^{\star \star \star}$ & $162 \cdot 30$ & $227 \cdot 40$ & 248.93 & 261.42 & $15 \cdot 803$ \\
\hline Protein $(\mathrm{g})^{\star \star \star} \ddagger$ & 87.50 & 131.61 & $159 \cdot 70$ & $182 \cdot 22$ & 7.573 \\
\hline Methionine $(\mathrm{mg})^{\star \star *}$ & $1616 \cdot 3$ & $2263 \cdot 8$ & $2623 \cdot 0$ & $3125 \cdot 0$ & $130 \cdot 98$ \\
\hline
\end{tabular}

Modelling nutritional needs for amino acids requires accurate information on the efficiency with which amino acids are used for various body processes. The classical protein evaluation methods - biological value and protein efficiency ratio - do not provide the vital information on the efficiency with which individual amino acids are utilized for body processes, and there is hence a need for direct investigation of individual amino acids. There is a considerable difference of opinion regarding whether the above-maintenance efficiency of amino acid utilisation is variable or constant in growing animals fed graded dietary levels (to near-optimal) of a limiting amino acid (Baker, 2004). Data acquired in the current study on methionine and protein retention indicate the following important points: between 2.4 and $3.9 \mathrm{~g}$ (near-optimal) digestible methionine/kg diet, the above-maintenance efficiency of methionine retention in White Pekin ducks from 22 to $42 \mathrm{~d}$ post-hatching was constant, the above-maintenance efficiency of retaining digestible methionine was $31 \%$, and at all levels of digestible methionine intake, there was an accretion of $15 \mathrm{mg}$ methionine/g body protein accretion.

Over the years, there has been controversy over the constancy of efficiency of amino acid utilisation for retention and whether diminishing returns occur at amino acid intakes above maintenance level (Heger \& Frydrych, 1985; Baker, 1991; Adeola, 1995, 1998; Timmler \& Rodehutscord, 2003). To the current author's knowledge, there are no published data on studies considering the efficiency of methionine retention in ducks. The observation

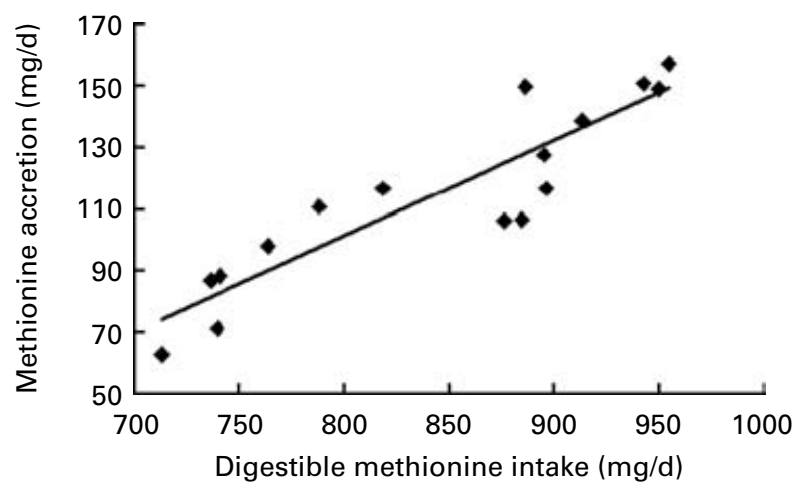

Fig. 1. Methionine accretion rate in the body $(\mathrm{mg} / \mathrm{d})$ as a function of daily digestible methionine intake $(\mathrm{mg} / \mathrm{d})$ of ducks fed diets containing supplemental methionine at $0,0.5,1.0$ or $1.5 \mathrm{~g} / \mathrm{kg}$ diet from day 22 to day 42 post-hatching. The regression equation was $y=-148.86$ (SE 32.558) +0.312 (SE $0.0384) \mathrm{x}, r^{2}=0.8253$. that methionine accretion is a linear function of methionine intake in the current experiment is in agreement with previous work from this laboratory on tryptophan retention in 3-6week-old ducks (Adeola, 1998). The constancy of efficiency of methionine retention in the present study is of particular interest as it illustrates that the dietary concentration of other amino acids relative to methionine had no pernicious effects on the utilisation of methionine.

Previous studies in 1-3-week-old ducks show a variable above-maintenance efficiency of valine retention (Timmler \& Rodehutscord, 2003), suggesting the occurrence of diminishing returns at valine intakes above maintenance level. In earlier studies with rodents, Heger \& Frydrych (1985) and Gahl et al. (1991) reported a variable efficiency of retention of threonine and lysine. The role of coprophagy in the observations by Heger \& Frydrych (1985) and Gahl et al. (1991) cannot be quantified and may be responsible for the observations, as Baker et al. (1996) suggested. The current data, as well as the lysine retention data of Batterham et al. (1990), Adeola (1995) and Heger et al. (2002) with pigs, the lysine, isoleucine and valine retention data of Baker (1991) and Baker et al. (1996) with chicks, and the data on branched-chain and large-neutral amino acids from Heger et al. (2003) with pigs, lend support to the notion that, within a range of limiting amino acid intake that is close to optimal, the above-maintenance efficiency of retention of an individual amino acid is constant.

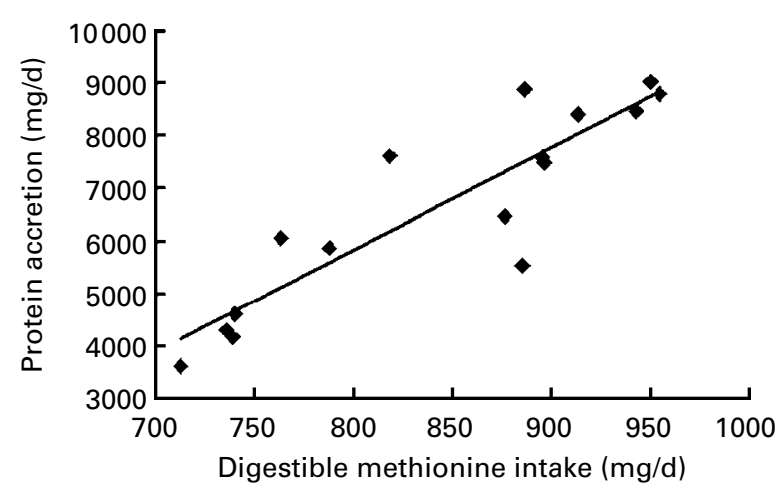

Fig. 2. Protein accretion rate in the body $(\mathrm{mg} / \mathrm{d})$ as a function of daily digestible methionine intake $(\mathrm{mg} / \mathrm{d})$ of ducks fed diets containing supplemental methionine at $0,0.5,1.0$ or $1.5 \mathrm{~g} / \mathrm{kg}$ diet from day 22 to day 42 post-hatching. The regression equation was $y=-9782$ (SE 2204) + 19.505 (SE 2.5994) $x$, $r^{2}=0.8009$. 


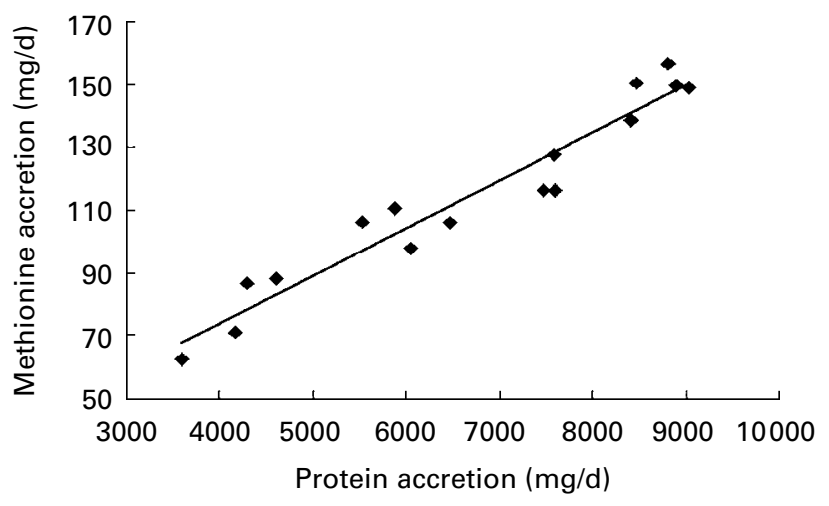

Fig. 3. Methionine accretion rate in the body $(\mathrm{mg} / \mathrm{d})$ as a function of protein accretion rate $(\mathrm{mg} / \mathrm{d})$ in ducks fed diets containing supplemental methionine at $0,0.5,1.0$, or $1.5 \mathrm{~g}$ per $\mathrm{kg}$ from day 22 to 42 post-hatch. Regression equation was $\mathrm{y}=12.757 \quad(\mathrm{SE}=7.4019)+0.01525 \quad(\mathrm{SE}=0.00107) \mathrm{x}$ $r^{2}=0.9355$

Linear regression relating methionine accretion to intake indicated that the efficiency of methionine retention in ducks was $31 \%$. The literature is replete with estimates of amino acid retention efficiency in pigs and broiler chickens. In experiments with growing pigs, Batterham (1994) reported efficiency values for lysine, threonine, methionine and tryptophan of $75 \%, 64 \%, 45 \%$ and $38 \%$, respectively; Bikker et al. (1994) reported a value of $74 \%$ for lysine; and Adeola (1995) estimated efficiency values of $72 \%$ and $60 \%$ for lysine and methionine, respectively. Using $\mathrm{N}$ balance in pigs has resulted in a range of efficiency estimates between $66 \%$ and $91 \%$ for a variety of indispensable amino acids (Heger et al. 2002, 2003). Methods using graded doses of amino acids in broiler chickens provided estimates of amino acid retention efficiency values of $82 \%, 80 \%, 73 \%$ and $61 \%$ for threonine (Edwards et al. 1997), lysine (Baker, 1991), valine (Baker et al. 1996) and isoleucine (Baker, 1991), respectively.

A $31 \%$ efficiency of retention of methionine in the current study on ducks together with the $49 \%$ estimate for valine from Timmler \& Rodehutscord (2003) on ducks and the $21 \%$ estimate for tryptophan from Adeola (1998) point to the conclusion that the efficiency, above maintenance level, of amino acid retention is different for individual amino acids in ducks. A retention of dietary methionine with an efficiency of $31 \%$ in the current study indicates that more than $50 \%$ of the digested and absorbed methionine was used for purposes other than the synthesis of retained protein. As discussed by Shoveller et al. (2005), three important metabolic functions of methionine are: protein synthesis; transmethylation to form a primary methyl donor, $S$-adenosylmethionine, which is important in a variety of metabolic reactions; and transsulfuration to cysteine, which in turn is catabolized to taurine or incorporated into glutathione. Methionine metabolism to these putative derivatives, together with its oxidation during the normal physiological process of growth, accounts in major part for the low efficiency of methionine retention.

The observation that the methionine, cysteine, arginine and threonine concentrations of body protein increased in response to supplemental dietary methionine concentration is in agreement with previous work in which there were increases in the concentration of a variety of amino acids in body protein from pigs and broiler chickens with increasing concentrations of dietary amino acids (Heger \& Frydrych, 1985; Chung \& Baker, 1992; Bikker et al. 1994; Adeola, 1995, 1998; Edwards et al. 1997). Furthermore, the amino acid intake-related changes in body amino acid concentration noted in the current study are consistent with the expected increase in proportion of contractile proteins relative to collagen protein. As the intake of a limiting amino acid increases, there is a larger increase in the concentration of indispensable amino acid in body protein owing to the larger proportion of contractile proteins relative to collagen protein (Bikker et al. 1994). The observed changes in concentration of some amino acids in body protein are indicative of the dependence of body amino acid concentration on nutrient intake. It is noteworthy that the accretion of $15 \mathrm{mg}$ methionine/g body protein accretion in ducks between 22 and $42 \mathrm{~d}$ post-hatching fed $2 \cdot 4-3.9 \mathrm{~g}$ digestible methionine/ $\mathrm{kg}$ diet is remarkably similar to the $16 \mathrm{mg}$ methionine/g protein gain in ducks between 1 and $22 \mathrm{~d}$ post-hatching fed $7 \cdot 1-12.7 \mathrm{~g}$ valine $/ \mathrm{kg}$ diet (Timmler \& Rodehutscord, 2003).

In summary, for ducks from 22 to $42 \mathrm{~d}$ post-hatching, there was a constant utilisation of methionine over the range of intake $2.4-3.9 \mathrm{~g}$ digestible methionine $/ \mathrm{kg}$ diet, with an efficiency of $31 \%$, and in each gram of protein accretion, there was a retention of $15 \mathrm{mg}$ methionine.

\section{Acknowledgements}

The author is grateful to the laboratory technicians and student workers of the Nonruminant Nutrition Laboratory for their assistance with experiments and laboratory analysis, to the staff of Purdue Animal House and Poultry Research Unit for their assistance with the daily management of the experimental animals, and to Maple Leaf Farms, Syracuse, IN, USA for donating ducks and feed. This study is Purdue Agricultural Research Programs Journal Paper No. 2006-17 885.

\section{References}

Adeola O (1995) Dietary lysine and threonine utilisation by young pigs: efficiency for carcass growth. Can J Anim Sci 75, 445-452.

Adeola O (1998) Bioavailability of tryptophan in soybean meal and tryptophan retention in the carcasses of four-week-old ducks. Poult Sci 77, 1312-1319.

Association of Official Analytical Chemists (2000) Official Methods of Analysis, 17th ed., Arlington, VA: Association of Official Analytical Chemists.

Baker DH (1991) Partitioning of nutrients for growth and other metabolic functions: efficiency and priority considerations. Poult Sci $\mathbf{7 0}$, $1795-1805$.

Baker DH (2004) Animal models of human amino acid responses. J Nutr 134, 1646S-1650S.

Baker DH, Fernandez SR, Parsons CM, Edwards HM III, Emmert JL \& Webel DM (1996) Maintenance requirement for valine and efficiency of its use above maintenance for accretion of whole-body valine and protein in young chicks. J Nutr 126, 1844-1851.

Batterham ES (1994) Ileal digestibility of amino acids in feedstuffs for pigs. In Amino Acids in Farm Animal Nutrition, pp. 113-131 [JPF D'Mello, editor]. Wallingford, UK: CAB International.

Batterham ES, Andersen LM, Baigent DR \& White E (1990) Utilization of ileal digestible amino acids by growing pigs: effects 
of dietary lysine concentration on efficiency of lysine retention. Br J Nutr 64, 81-94.

Bikker P, Verstegen MWA \& Bosch MW (1994) Amino acid composition of growing pigs is affected by protein and energy intake. J Nutr 124, 1961-1969.

Chen B \& Shen T-F (1979) Arginine and lysine requirements of Mule ducklings. Poult Sci 58, 1316-1320.

Chung TK \& Baker DH (1992) Efficiency of dietary methionine utilisation by young pigs. $J$ Nutr 122, 1862-1869.

Edwards HM III \& Baker DH (1999) Maintenance sulfur amino acid requirements of young chicks and efficiency of their use for accretion of wholebody sulfur amino acids and protein. Poult Sci 78, $1418-1423$.

Edwards HM III, Baker DH, Fernandez SR \& Parsons CM (1997) Maintenance threonine requirement and efficiency of its use for accretion of whole-body threonine and protein in young chicks. Br J Nutr 78, 111-119.

Edwards HM III, Fernandez SR \& Baker DH (1999) Maintenance lysine requirement and efficiency of using lysine for accretion of whole-body lysine and protein in young chicks. Poult Sci 78, 1412-1417.

Elkin RG, Stewart TS \& Rogler JC (1986) Methionine requirement of male White Pekin ducks. Poult Sci 65, 1771-1776.

Gahl M, Finke MD, Crenshaw TD \& Benevenga NJ (1991) Use of a four-parameter logistic equation to evaluate the response of growing rats to ten levels of each indispensable amino acid. J Nutr 121, $1720-1729$.

Heger J \& Frydrych Z (1985) Efficiency of utilisation of essential amino acids in growing rats at different levels of intake. $\mathrm{Br} J$ Nutr 54, 499-508.
Heger J, Van Phung T \& Krizova L (2002) Efficiency of amino acid utilisation in the growing pig at suboptimal levels of intake: lysine, threonine, sulphur amino acids and tryptophan. J Anim Physiol Anim Nutr 86, 153-165.

Heger J, Van Phung T, Krizova L, Sustala M \& Simecek K (2003) Efficiency of amino acid utilisation in the growing pig at suboptimal levels of intake: branched-chain amino acids, histidine and phenylalanine and tyrosine. J Anim Physiol Anim Nutr 87, 52-65. National Research Council (1994) Nutrient Requirements of Poultry, 9th rev. ed., Washington, DC: National Academy Press.

Oluyemi JA \& Fetuga BL (1978) The protein and energy requirements of ducklings in the tropics. Br Poult Sci 19, 261-266.

Ragland D, Thomas CR, Elkin RG, Schafer DJ \& Adeola O (1999) The influence of cecectomy on metabolizable energy and amino acid digestibility of select feedstuffs for White Pekin ducks. Poult Sci 78, 707-713.

SAS Institute Inc. (2003) Statistical Analysis System Proprietary Software. Release 9.1. Cary, NC: SAS Institute Inc.

Shoveller AK, Stoll B, Ball RO \& Burrin DG (2005) Nutritional and functional importance of intestinal sulfur amino acid metabolism. J Nutr 135, 1609-1612.

Sklan D \& Noy Y (2004) Catabolism and deposition of amino acids in growing chicks: effect of dietary supply. Poult Sci 83, 952-961.

Timmler R \& Rodehutscord M (2003) Dose-response relationships for valine in the growing White Pekin duck. Poult Sci 82, $1755-1762$.

Wu L-S, Wu C-L \& Shen T-F (1984) Niacin and tryptophan requirements of Mule ducklings fed corn and soy-based diets. Poult Sci 63, $153-158$. 